\title{
PRACTICAL RESULTS OF EXPERIMENTS IN SEWAGE TREATMENT.*
}

\author{
By T. W. H. GARSTANG, M.R.C.S., D.P.H.,
}

Medical Officer of Health of Bucklow Rural and other Sanitary Districts.

Three days ago I prepared the very short paper which I have to submit to this meeting, but within those three days I have received so many applications to attend from persons interested in the question, whom I am delighted to welcome, but who may very possibly not be advanced students in the science of sewage treatment, that $I$ find myself at the last moment confronted with a practical difficulty: Either I must deliver an elementary lecture for their instruction, which would not be fair to the experts who are present; or I must address the latter from a point of view which assumes considerable knowledge of elementary facts. Perhaps I can compromise the matter by enumerating the principal points which are now commonly accepted, for the benefit of any learners present, and then proceed to open the discussion with the paper as already prepared.

We all now admit that it is possible to treat sewage so as to entirely avoid the formation of sludge. In this process it is quite unnecessary to employ chemicals. Mr. Dibdin, at Sutton, demonstrates this by his cinder filters (or " contact-beds," as I prefer to call them, in order to keep firmly before you the fact that the action which takes place is very different to a mere mechanical straining) ; Colonel Ducat at Hendon with a quite different arrangement of contact-bed; and Mr. Cameron at Exeter by aid of a closed tank. Finally, various workers are now engaged in showing that the same result can be attained in an ordinary open tank. These must be accepted as facts, and then we can proceed to examine results and build up theories about them.

It is supposed that the solid matters in sewage are entirely liquefied, under favourable circumstances, by anaërobic bacteria, and that the resultant solution is afterwards further purified by aërobic bacteria.

How to discover the best method of bringing these bacteria under control is the sewage problem of the day. Nobody will be rash enough to assert that any known system has reached finality; we are all still searchers and learners, and we can profit by one another's advances, no less than by one another's mistakes.

* Read before the North.Western Branch of the Incorporated Society of Medical Officers of Health, March, 1000. 
This meeting is unique in my short experience of this Branch, in that the members present are outnumbered by their visitors, and those visitors are all men practically interested in the subject of my paper, which has, perhaps, on the other hand, only a theoretical and scientific interest for the majority of medical officers of health. I much appreciate the honour which has been paid me alike by members and visitors in meeting at this somewhat out-of-the-way place to discuss my experiments.

My attention was first drawn to the subject by the remarkable series of papers read at the Leeds Congress in 1897, and the interesting and valuable discussion which followed them. I then made myself practically acquainted, by personal visits of inspection, with the principal sewage-works then generally referred to as typical of the new ideas of bacteriological treatment. First I visited Exeter, then Sutton and Hendon; and since that time I have frequently visited the Manchester Corporation works at Davyhulme, where most important experience of actual working is being daily accumulated; also Oswestry, Crewe, Birmingham, Accrington, Chesterfield, Middleton, and many other smaller places. Each of these has distinctive features, and it has been my ambition to devise a scheme which should include the best points of all, together with, if I could possibly find it, some original improvement of my own.

The Hale Works, which I have shown you to-day, embody at least three such original ideas, which, although shown in combination, are really independent of each other, and had better be described separately before concluding with a few words on the rectual scheme in operation.

I purposely call the works "experimental," although they are working on the practical scale of dealing with the whole of the sewage of the township of Hale, which is about 150,000 gallons per day in dry weather, rising to upwards of 500,000 in times of rain. I do so because I fully recognise the possibility of further improvements, and because the object of this meeting is specially to invite criticism and discussion, from which I shall hope to profit in the future.

The first point which I recognised as a vital necessity, and upon which I feel that I cannot lay too much stress to-day, is the provision of an antomatic mechanism for breaking up the regular flow of sewage into separate quantities, which shall be intermittently delivered in different directions. This is done by the mechanism which you have just seen, which has the further advantage that it is actuated by the flow of the sewage itself, and so, when once 
installed, working expenses are reduced to a vanishing-point. The mechanism was devised by Mr. Ridgway, who is present to answer any questions about it. $\mathrm{He}$ is entitled to the whole credit for his ingenious invention as a mechanical engineer. Messrs. Mather and Platt, of the Salford Iron Works, have built the machine for him, which is sufficient guarantee of excellent workmanship. The scientific principle, however, which the machine is designed to carry out is applied according to an idea of my own, and for the originality of that idea I put my claim formally on record. Similarly, Mr. MeKenzie, the Surveyor and Inspector to the Bucklow Rural Council, is entitled to all credit for designing and executing the civil engineering works which, along with the mechanism, complete the scheme as far as it has gone. Mr. McKenzie also is present, and will answer any questions as to his department. You have seen two machines at rork; the first of these commenced on December 17th, 1898, so that it has weathered two winters. In the late severe storm a few weeks ago the frozen snow on the cams threw it out of work, but with this exception it has never failed to perform its work automatically to our complete satisfaction. As it was purposely left exposed to the weather, in order to malie the trial as severe as possible, any repetition of this accident can be easily avoided by simply boxing it in. I do not propose to waste time in arguing about this machine. If you grant that the object with which I started is a proper one, then I can conscientiously certify that it is fully, completely, and satisfactorily carried out by Mr. Ridgway's invention.

As a matter of form, I will briefly recapitulate the description. The sewage flows uniformly into a chamber at the rate of 72,000 gallons per day; the chamber holds 1,000 gallons; it is discharged once every twenty minutes by a siphon. This occupies four minutes. The discharge is then received in a second chamber, one side of which is formed by a metal plate containing a number (seven) of openings, each closed by a heavy lid hinged to an upright lever, so arranged that the lid is raised by the pressing back of the lever by a cam fixed upon a shaft in such wise that only one of the series is in operation at one time. A metal float in the first chamber continually rises and falls by the filling and emptying of that chamber, and by a pawl and ratchet-wheel causes the revolution of the shaft at each discharge of the siphon exactly one-sixth of a circle. Each partial revolution therefore effects the closing by its own weight of the lid which (when held open) received the last discharge, and opens the next lid, so that the discharge then taking place passes through the next outlet in succession. Of the seven openings, one 
is commonly not in use, but is so arranged that it can be brought into the series to take the place of any one of the other six which it may be desired to throw temporarily out of work. In this installation each outlet leads to a separate contact-bed. So much for the mechanism. Please note that it is suitable for almost any kind of sewage works, and would be especially valuable in places where broad irrigation is still used, plots of land taking the place of contact-beds. Its use is in no way confined to this particular scheme of works. Further information as to any mechanical details will no doubt be able to be obtained from the makers.

The second point which appeared to me desirable of attainment requires a little more explanation. Although excellent results are obtained by the Dibdin process, equally good are obtained by the Ducat filter. It would thus appear that either aërobic or anaërobic organisms can be made available. My selection bas been made upon this assumption, and I have devised a contact-bed which will deal with the intermittent discharges from the distributor without requiring any manual labour such as is required in the Dibdin process for the opening and closing of valves at stated periods. To be brief, I find that sewage will run through a new cinder contact-bed without check for a time; that an oversupply of serage will ultimately choke the bed, so that nothing at all will pass through; and that between these two extremes there exists the happy mean where the sewage will flow through the bed at exactly such a rate as the operator may wish. By attaining this mean the outlet of the contact-bed may be left permanently open, and yet the sewage will pass through the bed so slowly that it will attain as much purification as if it had been treated by the genuine Dibdin process. My contact-beds are formed of waste cinders, double-riddled so as to retain only those between $\frac{1}{8}$ inch and $\frac{3}{4}$ inch. In this particular instance each contact-bed has a capacity of about 2,000 gallons for sewage in the interstices of the cinders, and as 1,000 gallons only is delivered on to its surface once in every two hours, and gradually percolates through the body of the bed without hindrance, except from the organic matter already deposited there, it must be evident that the upper layers of the bed at all events undergo very thorough aëration. The sewage itself is well aërated at three points in its course-viz., in falling into the siphon-chamber, in discharging into the distributing-chamber, and in being delivered upon the surface of the contact-bed. Thus, the method of treatment in the upper part of the contact-bed exactly follows the original definition of the Massachusetts State Board of Health-viz., "the passage of thin films of liquid over surfaces in 
the presence of air." As to what happens in the lower part of the bed, I am not prepared to speak so definitely; but I am quite content to stand upon results. From the chart of analyses by the

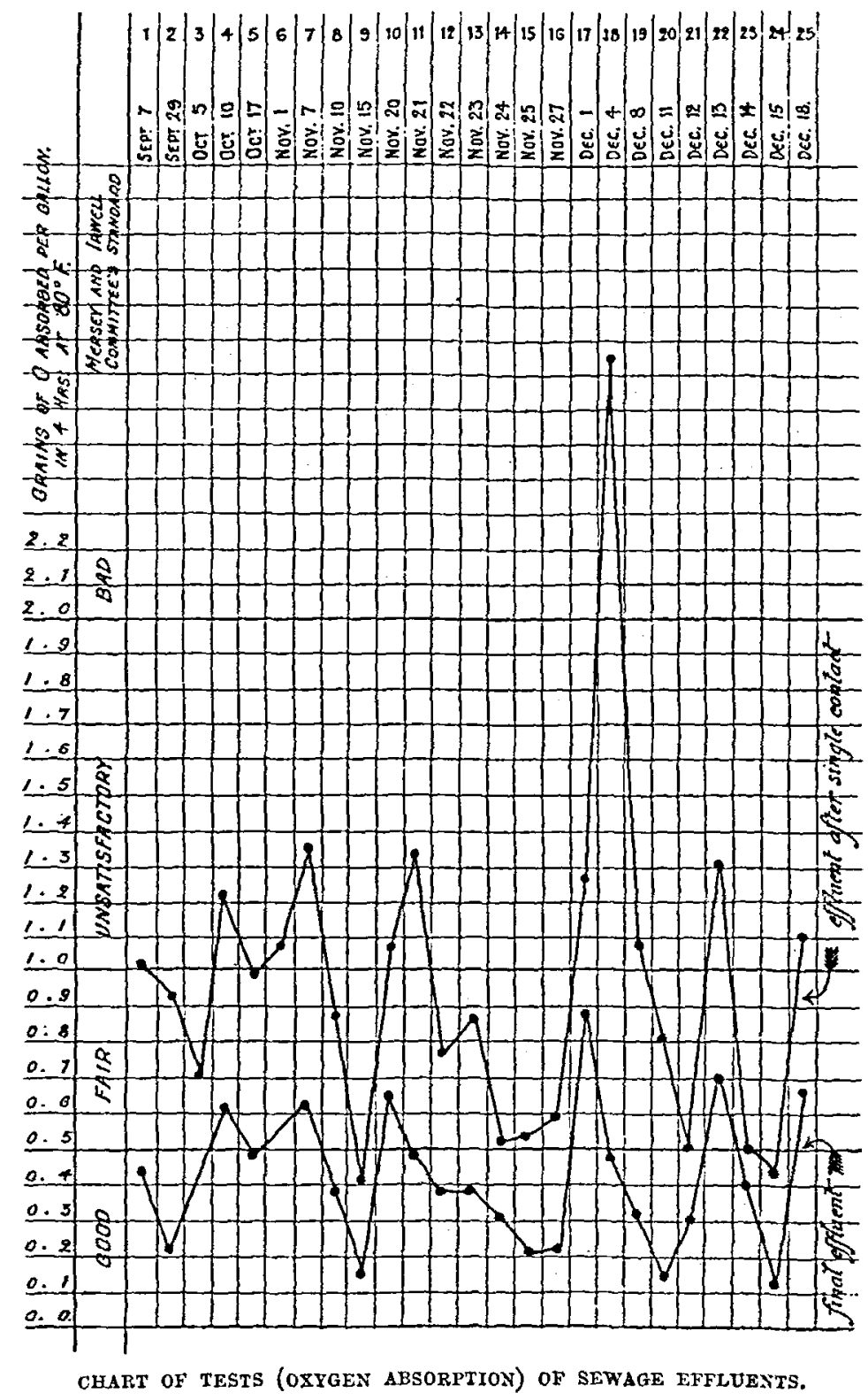

"oxygen-absorption" process, it will be easily seen that we have every reason to be satisfied. With a crude sewage about 4.0 (grains of oxygen absorbed per gallon in four hours at $80^{\circ} \mathrm{F}$.), 
the effluent (from a single contact-bed) averages $1 \cdot 0$, or less, and the final effluent (after passing over a small area of land) averages only about 0.5 , or less.

My diagram is open to criticism on two grounds, viz., that the dates of the analyses are separated by irregular intervals, and that the samples taken on each date may possibly not represent the true average of that day's work. The reply to this is that there is no staff to give continuous attention to the taking of samples, and that I must either go without samples altogether, or be satisfied with such as can be taken haphazard on such days and at such hours as chance to be convenient for the inspector or his assistant to visit the farm when in the neighbourhood on other business. As a matter of fact, I do not myself believe that the diagram is any worse for these circumstances, for it must be admitted that it accurately represents just such sampling as is done in practice by the Mersey and Irwell Joint Committee, and, after all, that is the only standard to which we are compelled to conform. In the diagram every result is given between the first and last dates shown ; nothing is omitted, and nothing is "cooked." I think it may be accepted as an honest record of the results normally obtained. I therefore venture to direct attention to it with a certain degree of confidence. On December 4th the only bad result noted was found, and it was afterwards ascertained that the cause of this was the temporary necessity of discharging a small quantity of crude sewage into the channel which normally conveys filtrate only. Omitting that single result, it will be observed that the final effluent out of twenty-two analyses was three times below 0.2 , three times again below $0 \cdot 8$, seven times again not exceeding 0.4 , and four times not exceeding 0.5 , making seventeen times when the effluent was "Good"; whilst none of the remaining five exceeded $0 \cdot 7$, and so were all well within the "Frir" class. This result is sufficiently satisfactory, and yet I am even more proud of the intermediate results given by the effluent after single contact. This stage is not supposed to show anything approximating to a finally good result, yet, as a matter of fact, the diagram shows that this effluent would have been classed four times as "Good," and ten times as "Fair"; whilst on the remaining ten occasions it never reached $1 \cdot 4$, and would therefore have been only moderately " unsatisfactory," even if it had been the final effluent instead of only the intermediate stage. The crude sewage is not shown on the diagram, but its average strength had in earlier experiments been settled to be about $4 \cdot 0$, so that critics are welcome to the admission that the Hale sewage is a particularly mild specimen of the purely 
domestic variety. But when all this is allowed for, the results still remain, in my opinion, little short of marvellous, when it is added that during the past twelve months every square yard of this contact-bed has dealt with a minimum quantity of 400 gallons per day, and that on most days this amount has been exceeded, and on some days even doubled. Calculated by the acre, this corresponds roughly to a minimum of $2,000,000$ gallons per day, with a larger quantity on most days, occasionally touching a maximum of $4,000,000$. The length of time over which the work has been carried on is sufficient to preclude the suspicion that the results obtained have been merely accidental or unreliable. I am not aware of any other system of sewage treatment which makes any pretence to attain such results.

This may be the best place to explain that the works are incomplete. In carrying them out, on account of their experimental nature, it has been necessary to proceed with great caution, and to fully prove each step before taking the next. We have spent two years in arriving at the present position, and more remains to be done to make the works complete. I have invited you to meet to-day, at an earlier date than I would otherwise have liked, for the following reason: After the expiration of this month the greater part of the township of Hale (including the whole area which drains to these works), which has hitherto been a portion of the Bucklow Rural District, will attain to independence as a new urban district. This new district will, of course, appoint new officers, and it is therefore impossible for me to predict what will be done with the sewage works. It is, of course, quite on the cards that my views may not find favour, and that the concrete expression of them may be swept away, so that if I wished you to inspect the peculiar features of my scheme it became necessary to call you together before the end of March, without considering the condition of completeness or incompleteness of the works themselves.

The previous remarks have applied to the older contact-beds. You have also seen a newer and slightly larger set of contact-beds being worked in the same manner, which commenced work on January 30th, 1900. These, therefore, are not yet "ripe," and I say nothing further about them, except to remind you that in this case the sewage passes through a large tank before being distributed; and it is both interesting and important to note the great difference between the crude sewage treated at the old beds, and the tank effluent treated at the new beds. The former contains solid matter in a very crude form, and varies considerably from hour to hour; the latter is of fairly constant strength, and is a liquid containing 
only the finest possible particles in suspension. The solid matter has here undergone bacteriolysis in the tank, and I confidently expect to find that a much larger quantity of tank effuent can be treated on a given area of contact-bed than is the case with the crude sewage.

In another set of experiments which I made in a neighbouring district (Knutsford) in the summer of 1898 , I demonstrated successfully this bacteriolysis, or destruction of sludge by bacteria, in an open tank.

On September 1st, 1898, I made the following report on "further" observations at the sewage outfall-works" to the Knutsford Urban District Council :

"By special permission of the Council, given at the meeting held on July 5th, I was authorized to convert the tanks temporarily into a ' continuous-fiow' tank, and observe the results. . . . In estimating results observed, it must be borne in mind that during this period there was no rain, and the sewage was therefore of exceptional strength ; also that the weather was unusually hot, so that fermentative and putrefactive changes took place with considerable rapidity. . . The continuous flow tank gives quite as good a result as the older system, so far as tank effluent is concerned. ... Another important question was: what would happen to the sludge? When the tanks were run off on July 30 th this was answered. Nearly all the sludge was retained in No. 1 tank; some which was found in the other tanks was due merely to imperfect arrangements, and could be almost entirely avoided in any future application of the system. I had the depth of sludge carefully measured; it was 12 inches at the deepest part in the centre. It marked barely 6 inches at the iron gauge at the end, and it was 2 inches along the sides (in No. 1 tank). ... This shows a much smaller total quantity than would have accumulated under ordinary circumstances."*

The same thing has since been done by several independent observers; but I am not aware at the present moment of any published report on the subject bearing date anterior to mine.

I now come to the third point which I have to explain. In addition to working the contact-beds as described, I carried out another series of experiments by raising the level of the outlets, and draining each bed from its lowest point by a pipe communicating with such outlet. I found in practice that better results could be thus obtained than from the plain open contact-bed. I suppose

\footnotetext{
* There were three tanks, each holding 97,000 gallons, and the daily flow of sewage was upwards of 150,000 gallons. The " ordinary circumstances " alluded to were: precipitation by large doses of alumino-ferric, and the removal of sludge mechanically from each tank twice a week, the tanks being worked in succession. The new experiment showed that, with continuous flow, and no chemicals, no mechanical removal of sludge was needed within the twenty-two days over which the experiment extended. Many other allied points had been dealt with in previous reports.
} 
that anaërobic action takes place in the water-logged bottom of the bed, following the aërobic treatment attained in the upper part of the bed; and, without stopping to argue unduly the theoretical rights or wrongs of the matter, I will briefly say that all the beds which you have seen to-day have been constructed upon this principle. But in order not to diminish the space available for aërobic treatment, the beds have been somewhat deepened, so that the space now occupied in the lowest level is below that which was originally designed for the aërobic bed. What now occure is this : Each discharge placed upon the surface of any given bed forces out in front of it through the rising pipe the previous discharge which has been lying in the bottom of the bed for two hours; and itself, after aërobic treatment in its passage through the body of the bed, lies at rest in the deepest part for another two hours, and is then itself expelled by the next succeeding discharge which comes upon the surface. As I have already said, I am not yet prepared to formulate a complete theory as to the exact action which takes place. I may, however, add this observed fact-that the discharge from such a bed is always faintly opalescent, and generally smells of sulphuretted hydrogen. In spite of this, it always gives a good result with the oxygen-absorption test, and after passing over land it yields a thoroughly satisfactory effluent to the river. The percentage of additional purification obtained by the land treatment is often surprisingly small. I need hardly add that my own wishes would discard the land altogether, and replace it where necessary by further contact-beds.

It only remains to summarize as briefly as possible what you have actually seen. The main sewer delivers upwards of 150,000 gallons per day according to weather, of which not less than 72,000 (and frequently considerably more) is placed upon the older contactbeds, which cover 180 square yards; another quantity, varying from 50,000 to 100,000 gallons, is taken to the new tank and contact-beds. These beds are 240 square yards; but the amount which can be placed upon them is limited by the capacity of the tank, and we are working this cautiously so as not to cause an undue accumulation of sludge. The capacity of the tank is about 50,000 gallons. A third channel remains available for another portion of sewage if necessary. This leads directly, without other treatment, on to a separate portion of the land where broad irrigation takes place. The effluent from this land is always inferior in quality to either of the other effluents from the portions of land containing respectively the old and the new contact-beds. When the flow of sewage exceeds about 350,000 gallons, the surplus passes 
direct into the river by means of the original overflow, which exists to-day exactly as it was constructed twenty years ago. To deal more satisfactorily with this overflow is one of the problems which I have had under consideration, but which, owing to the circumstances already detailed, it will probably now fall to somebody else to solve.

Bofore concluding, I must not omit to draw your attention very strongly to the enormous proportionate amount of sewage with which the older contact-beds have continuously dealt for a period of fifteen months. This has never been less than 400 gallons per square yard per day (or 2,000,000 gallons per acre), and has frequently been more, and occasionally very much more. Had we been content with less, we could undoubtedly have obtained even better results than those I have quoted; but we have been deliberately worling the beds up to their very utmost capacity, partly because it was a practical service to deal with as much sewage as possible, but more particularly because we wished to ascertain what such beds could actually perform under pressure. I believe, subject to correction if I am wrong, that there are no sewage works in the kingdom which profess to deal with anything like such quantities as we have successfully treated here (in proportion). Thether our success be due to the automatic distributor, or to the method of working the open contact-bed (in contrast to the Dibdin bed), or to the addition of a lower space wherein some action (not yet fully recognised) takes place, I will not venture to say dogmatically. I will merely remind you that these three features are quite independent of each other, and that, although I have personally preferred to combine them, it is, of course, open to any other experimenter to make use of, or to discard, any one of them at his own discretion.

My remarks have been very greatly compressed, to bring them within the scope of a short paper. If I have left any points insufficiently explained, I will be glad to go into them more fully on another occasion with any inquirer; for I fear that time will not permit of a full reply to-day, and I would much prefer that such time as remains to us should be rather occupied by the criticisms of others than devoted to the repetition of my personal (and perhaps you may think peculiar) opinions.

\section{DISCUSSION.}

Dr. HAyward thanked Dr. Garstang for his most interesting description of the Hale Sewage Works, and of the work that was being carried on there.

Mr. Russelc HaLl asked whether sewage should remain standing in the filter for a time, or run straight through? 
Mr. Grivshaw asked whether better results had been obtained with the beds acting in conjunction with the septic tanks, or with the others? He said the only works which dealt with anything approaching $2,000,000$ gallons per acre \& day were at Accrington, and there the beds were 9 feet deep and the sewage was warmed. He desired to express his appreciation of the manner in which the automatic apparatus was working.

Dr. Youvg asked under what circumstances the Local Government Board standard mentioned had been laid down.

Dr. Sergeant thought that the best principles of sewage treatment had been adopted by Dr. Garstang. He was pleased with the automatic distributor.

Mr. FowLer (Chemist to the Manchester Sewage Works) said an automatio apparatus for feeding the filters was very desirable, and that at Hale appeared to work well. It, however, required a good fall, so that it might not be suitable for some works. One reason for the efficiency of these beds was that the flow was intermittent, and that the charge was small and frequently repeated. Probably there was a certain amount of anaërobic action at the bottom of these beds. A similar action was noticed in the Manchester experiments. When the discharge-pipes were allowed to remain full, there was after standing a blackish deposit. He thought sufficient attention had not been given to the sanitary aspect of the question, and that it would be very discouraging to the chemist, after solving the problem of disposing of the sewage, to find that the diseaseproducing organisms had not been rendered harmless.

Dr. Garstang replied briefly.

Disinfection of Vessels. * The usual methods employed in the Canadian Quarantine Service for the disinfection of vessels are as follows: Steam for all hospital cabins and other small apartments where it can be used; formaldehyde for saloons, state-rooms, and small apartments where the permanent fittings would be destroyed by steam; sulphur dioxide gas, under pressure from the blast furnace, for holds and steerages; and mercuric chloride solution for all free surfaces, alleyways, latrines, bilges, etc. Steam is not suitable for large apartments, as the temperature cannot be kept up, and the steam is therefore precipitated as simple hot water. Last June a ship arrived in the St. Lawrence with 2,300 immigrants from Batoum on board and a crew of sixty-nine. Cases of small-pox existed among both. Every one and the heavy luggage from the hold were landed, the ship disinfected, and a new crew put into her four days later. On this occasion formaldehyde was used for the holds and steerages, being liberated from formalin, 12 ounces of which were allowed for each 1,000 cubic feet of space, with an exposure of eight hours. No further cases occurred subsequently. Formaldehyde has also been employed for the purification of some of the United States transports after service at Cuba.

* From paper read by F. Montizambert, M.D., Director-General of Public Health, before the Canadian Medical Association, August 30th, 1899.-Afontreal Medical Journal, October, 1899. 